\title{
Transcending Boundaries: The Acousmatic Story in the Anthropocene
}

Joanna Dobson \& Julia Schauerman ${ }^{1}$

Sheffield Hallam University \& University of Sheffield, United Kingdom

The multiple crises of the Anthropocene include a crisis in storytelling. Amitav Ghosh, for example, has claimed that not only is literary fiction incapable of representing climate change, it is also complicit in its concealment in the broader culture (2016). Ghosh suggests the increasing entwining of image and text brought about by the Internet could lead to a hybridity of form that will free readers from the unhelpful logocentrism of recent times. While agreeing with him on both the need for new forms and the importance of hybridity, we argue that he has overlooked the power of sound in storytelling. Drawing on a collaborative work-in-progress about birdsong and loss, we propose the acousmatic story as a response to the challenges of the age and also to an emerging understanding that all stories are entangled in a vast mesh of agencies, both human and other-than-human.

Keywords: acousmatic story, Anthropocene, birds, climate change, Amitav Ghosh, vital materialism

1 Joanna Dobson (jcdobson@my.shu.ac.uk) is a PhD student in English and Creative Writing in the Culture and Creativity Research Institute at Sheffield Hallam University, United Kingdom. Julia Schauerman (jmeschauerman1@sheffield.ac.uk) is studying for an MA Composition (Electroacoustics) in the Department of Music at the University of Sheffield, United Kingdom. The authors would like to thank Dr Harriet Earle of the Department of English, Sheffield Hallam University, and Professor Adrian Moore of the Department of Music at the University of Sheffield for helpful comments on an early draft of this article. 


\section{Imagined Boundaries}

This article arose out of a collaborative storytelling project between the authors. The work-in-progress, Imagined Boundaries, uses declining bird populations to explore loss from different perspectives and on different scales and time frames. It takes the form of an acousmatic story, blending spoken word, soundscape recordings and manipulated sounds.

\begin{tabular}{|c|c|c|}
\hline Timing & Section & Description \\
\hline 0:00 & Marsh harrier & A single bird calling (shrill disyllabic) \\
\hline $0: 30$ & Time of birds & $\begin{array}{l}\text { Increasing layers of bird song } \\
\text { Naming birds } \\
\text { Poem: The Creation of Birds (Paradise Lost, John } \\
\text { Milton) }\end{array}$ \\
\hline $4: 30$ & Anthropocene & $\begin{array}{l}\text { Theme: Industrial sounds, drones and } \\
\text { disembodied flapping }\end{array}$ \\
\hline $7: 30$ & Personal story & $\begin{array}{l}\text { Memories: Bird watching, the last pair of marsh } \\
\text { harriers and personal loss }\end{array}$ \\
\hline 9:30 & $\begin{array}{l}\text { Earth, air and } \\
\text { rain }\end{array}$ & $\begin{array}{l}\text { Poem: Proud Songsters (Thomas Hardy) } \\
\text { Instrumental sounds }\end{array}$ \\
\hline $10: 30$ & Changes & $\begin{array}{l}\text { Anthropocene theme mixed with weather and tidal } \\
\text { sounds. } \\
\text { Scientists (past and present) reflecting on the } \\
\text { impact of humankind on the planet }\end{array}$ \\
\hline $14: 30$ & Remembering & $\begin{array}{l}\text { Attempts to remember places visited and birds } \\
\text { seen } \\
\text { Rural sounds empty of bird song }\end{array}$ \\
\hline $16: 30$ & Just a robin & Talk of the only bird visiting the garden \\
\hline $17: 00$ & $\begin{array}{l}\text { Attempted } \\
\text { facsimile }\end{array}$ & $\begin{array}{l}\text { Poem: 'The Selfsame Song' (Thomas Hardy) } \\
\text { Trying to recreate the sound of birds with voice } \\
\text { and instruments, gradually transformed into a } \\
\text { lament }\end{array}$ \\
\hline 19:00 & Quest & $\begin{array}{l}\text { Memories: RSPB board game Conservation and } \\
\text { equipment for bird watching. The success of the } \\
\text { marsh harrier intervention. Scientist exploring } \\
\text { what can be done }\end{array}$ \\
\hline 22:00 & Anthropocene & Gradual emergence of theme \\
\hline 23:00 & Marsh harrier & A single bird calling (shrill disyllabic) \\
\hline
\end{tabular}

Figure 1: Imagined Boundaries - composition overview

The idea for Imagined Boundaries arose partly from Joanna Dobson's work on a memoir centred on the death of her brother, Simon, and partly from Julia Schauerman's experience of recording birdsong during the first 
Covid-19 lockdown in the UK. Simon died in a road accident in 1971, when he was seven, and Dobson's parents barely spoke of it. This had severe psychological effects on all members of the family and made it difficult for them to function as a healthy unit. The only time when things were easier was when they were exploring the countryside on walks and holidays that frequently involved birdwatching and in particular pursuing rare species, such as the marsh harrier, which was then almost extinct in the UK. At the time, birdwatching was becoming enormously popular in Britain, alongside a growing concern about anthropogenic damage to the environment. Rachel Carson's Silent Spring (1962) had provided a shocking account of the way that pesticides were decimating wildlife, and the title referred to her opening chapter, in which she imagined an American town that had once throbbed to the sound of birdsong but suddenly fell silent. Imagined Boundaries also takes birdsong as a signifier of species decline, and weaves the story of Dobson's personal loss into a much bigger story of the catastrophic biodiversity loss that is one feature of the Anthropocene. Schauerman's overview of the composition is shown in Figure 1.

Through our collaboration we have come to believe that acousmatic storytelling is a fluid and supple form that is ideally suited to the profound challenge of telling stories in the face of the multiple crises of our times.

\section{Introduction}

In arguing for the importance of acousmatic storytelling for the Anthropocene, we engage with Amitav Ghosh's acclaimed non-fiction work The Great Derangement: Climate Change and the Unthinkable (2016), in which he writes that the prestigious, contemporary form of storytelling that he calls "serious literary fiction" is not only incapable of representing climate change, it is also complicit in its concealment in the broader culture. Ghosh suggests that climate change may even be resistant to language itself and predicts that new, hybrid forms of storytelling will have to emerge. He welcomes the rise of the graphic novel, with its intertwining of text and image (2016: 84). Similarly, he suggests that television, film and the graphic arts have been more successful than literary novels in addressing the climate crisis because their focus on the visual provides an escape from what he calls "the shadow of language" (82).

We agree on the need to find new ways of telling stories in these cataclysmic times. However, we argue that in an age so saturated in visual images, the need is not for more pictures but rather for a rediscovery of the subversive power of sound to awaken the imagination and bring about shifts in perspective. Our stance is in line with that of other thinkers and composers who have stressed the importance of "reclaiming sound as an essential, but undervalued, cultural and political resource" at a time of ecological crisis (Comstock and Hocks 2016: 166). Bernie Krause (2012), for example, has drawn attention to the way that soundscape recordings can chart both the 
decline of more-than-human voices and the increase in human disturbances in a given place. Such recordings are representative of acoustic ecology, a field of research which emerged in the 1960s from the work of composer R. Murray Schafer, one of the first to draw attention to the dangers of sound pollution and the importance of preserving natural soundscapes (Pasoulas, 2020). Subsequent creative engagement by Schafer and his colleagues, including Hildegard Westerkamp and Barry Truax, with documented soundscapes resulted in soundscape composition (Westerkamp 2002).

Jonathan Gilmurray (2017) has highlighted the growing number of sound artists engaging with the environmental crisis and argued that this "powerful ecological art form" (32) deserves more recognition. David Ingram (2010) has compared the "holistic interconnectedness" (59) that hearing can engender with the sense of separation that sight can create between subject and object. He argues that the tendency of sight to be the dominant human sense has a negative impact on the environment. Similarly, Daniel Paiva and Eduardo Brito-Henriques have used podcasts to demonstrate how sound can convey the "affective contents" of a place in a way that the written word cannot (2019: 535). The work of Peter Cusack on "sonic journalism" is also relevant here. His Sounds From Dangerous Places (2012) presents field recordings from places of major environmental damage on an audio $\mathrm{CD}$ that is accompanied by a book presenting written and visual background information on the sites. So far, however, little attention has been paid to the potential of the acousmatic story for navigating what Ghosh calls "the wild currents of global warming" (2016: 8). Falk Morawitz has discussed the form in relation to his own composition On the Extinction of a Species; however, his emphasis is more on technique than narrative potential, specifically the broader use of spectroscopic data in music composition to raise awareness of environmental and socio-political challenges $(2019 a ; 2019 b)$. In this paper, we draw on recent work in ecological sound art and environmentally focused criticism, and use examples from Imagined Boundaries and other acousmatic stories to argue that the acousmatic story has a powerful role to play in communicating the current crisis.

We turn first to a more detailed explanation of what we mean by the terms "Anthropocene" and "acousmatic story".

\section{The Anthropocene}

"Anthropocene" is a widely used term that describes "the new epoch of geological time in which human activity is considered such a powerful influence on the environment, climate and ecology of the planet that it will leave a longterm signature in the strata record" (Macfarlane 2016: n.p.). It marks a break with the relatively stable era of the Holocene that preceded it, but geologists disagree about when it started and the term has yet to achieve official status. However, a majority of scientists on the Anthropocene Working Group recently voted to submit a proposal to the International Commission on Stratigraphy 
to have the Anthropocene formally recognised as a new epoch by 2021 , with a starting point of the mid-twentieth century (Subramanian 2019, n.p.).

The term "Anthropocene" has attracted considerable criticism. Donna Haraway (2016) is among those pointing out that the root word anthropos, from the Greek "human being" is precisely an example of the human-centredness that has led to the current crisis. She suggests instead Chthulucene, a neologism that references the complexities and connectedness of the biosphere. Jason W. Moore (2017) argues for "Capitalocene", aligning the origins of capitalism with those of the ecological crisis. Kathryn Yusoff (2019) criticises the term's recourse to a universal category of "man" without taking into account the intersections of the ecological crisis with colonialism and racial exploitation. In a similar vein, Jairus Grove (2019) has proposed the alternative term "Eurocene". The list goes on, but nevertheless we find "Anthropocene" useful as a way of referring to the multiple, largely anthropogenic crises affecting the planet today, including global warming, biodiversity loss, the sixth mass extinction event and the emergence of novel, zoonotic viruses.

\section{The acousmatic story}

Acousmatic storytelling is a way of telling stories that uses recorded spoken word set within a composed soundscape that evokes specific places and time periods. The term links it to acousmatic music, a type of electroacoustic music that is presented via loudspeakers. Very little has been written about storytelling in the field of electroacoustic music. In an article published in 1994, Katharine Norman explored the storytelling intentions of tape music composers who use real world sounds to reflect human experience and suggested that composing with recorded sounds can be particularly effective in stimulating memory and emotional responses in the listener. In a conference paper, the composer John Young (2009) explored the ways that acousmatic music can be combined with environmental and everyday sound to evoke narrative. Young's ideas were later developed in an important article by the composer and academic Panos Amelides (2016). Amelides describes the acousmatic story as "a hybrid vehicle for transmitting stories, derived from the incorporation of the specificity of language with the affordances of the manifold structures of sound" (2016: 213). In his definition:

Acousmatic storytelling integrates interviews, archival recordings, soundscape recordings, sonic icons and music quotations; the microphone becomes a time machine, "thought capturer" and a conduit for conveying cultural information, elements which, combined with the sonic world composed in the studio create a hybrid form (213).

For Amelides, the distinction between acousmatic storytelling and acousmatic music is that the manipulated or generated sounds are used to create context and enhance the recorded spoken word. He writes of the "balance and alternation between oral storytelling and composed world storytelling" required to produce holistic work (2016: 219). Amelides sees elements of this 
in some earlier works from the repertoire of electroacoustic music, citing particularly Luc Ferrari's Far-West News (2009); Hildegard Westerkamp's Kits Beach Soundwalk (1989), and Delia Derbyshire's Invention for Radio No 1: The Dreams (1964) (Amelides 2016: 217; 218; 219).

A strength of acousmatic storytelling is its ability to stimulate listeners' imaginations to form their own versions of the story. Thus the listeners become co-creators with the composer (Amelides 2016: 213). Amelides is particularly focused on the role of acousmatic storytelling as "a new medium of historical representation" (213). This is because the acousmatic storyteller uses archival material and historical research, along with interviews that show how the past connects with individuals and communities in the present day. We will argue that the approach has even wider potential than this and is particularly suitable for storytelling in the Anthropocene, or what Ghosh has suggested may come to be termed "the time of the great derangement" (2016: 11).

\section{The Great Derangement}

In The Great Derangement, Ghosh offers an analysis of modern literature, history and politics in which he argues that all three modes operate to occlude the severity of the climate crisis. "Let us make no mistake," he writes, "the climate crisis is also a crisis of culture, and thus of the imagination" (2016: 9). In this article, we focus on the first section of the book, "Stories".

The book has provoked mixed reactions. Neel Mukherjee described it as "one of the most powerful critiques of the varied foundational systems of Western thought" (2016: 59). Similarly, Jesse Oak Taylor judged it "one of the most sustained and thoughtful accounts of the novel in an age of climate change" $(2018,113)$. However, like others, he criticises Ghosh's assertion that science fiction belongs in the "generic outhouses" (Taylor 2018: 116; Ghosh 2016: 24). Ursula K. Heise, for example, cites numerous examples of science fiction works that are widely read and engage successfully with the climate emergency. To refuse to recognise this is, she writes, "a striking argumentative shortfall" (2018: n.p.). We agree that Ghosh's dismissal of science fiction is problematic; nevertheless we find his arguments important, given the prominence of the realist novel in Western literary culture.

Shortly after the tsunami on 24 December 2004, Ghosh visited the low-lying Nicobar Islands in the Bay of Bengal. Situated close to the epicentre of the undersea earthquake, the islands had suffered catastrophic damage. The coastal village of Malacca, for example, had been razed "literally to its foundations" (2016: 34). But what struck Ghosh the most was not the scene of devastation on the shore but rather the contrast with the island's almost undamaged interior (34). On investigation, he discovered that the indigenous islanders lived mainly in this interior. Those who had settled on the seashore were generally educated, middle-class incomers. Their decision to ignore gen- 
erations of understanding that it is wiser to build homes away from the ocean was an example of what Ghosh called "a kind of madness" (35). To be clear, Ghosh was not attacking the individuals who had suffered such a dreadful fate. They were simply following "accepted global norms", after the example of the European colonial powers who had founded cities such as New York, Bombay (Mumbai) and Hong Kong directly beside the ocean.

Ghosh is clear that culture, and specifically what he calls "serious literary fiction", shoulders a large share of the blame for such "utter recklessness" (2016: 55). He does not give a precise definition of "serious literary fiction", but implies it is the kind of work that features in journals like the London Review of Books, the New York Review of Books, the Los Angeles Review of Books, the Literary Journal, and the New York Times Review of Books (7). This approach is clearly contentious: it suggests a failure to recognise the class, gender and racial biases that often determine what gets published and where, and has attracted some criticism. Sadia Abbas, for example, describes such a reduction of what constitutes literature worth discussing as "an inflated rhetorical gesture" (2018: n.p.). That notwithstanding, the prestige associated with these journals and, by association, with the kind of fiction they discuss, means that their influence on mainstream culture is significant and merits critique.

Reading the journals, Ghosh finds almost no mention of the climate emergency. Amelides, however, explicitly states that, having begun as an acousmatic composer exploring sound for its own sake, he turned to acousmatic storytelling as he became "more urgently aware of a need to engage with the issues and themes of the world around me" and to expose cultural and political events "in a fresh way" (214). His desire to use his compositional skills more politically resonates with the work of Anja Kanngieser, who has called for sound to be recognised as a provocation to political thought that challenges the "hegemonic and violent forms of subjectivation" that have led to the crises that characterise the Anthropocene (2015: 80).

We now turn to a more detailed examination of how the acousmatic story can respond to the issues raised in The Great Derangement.

\section{The improbable everyday}

We begin with Ghosh's most serious accusation against literary fiction: that it is complicit in the concealment of climate change in the wider culture (2016: 11). To illustrate this, Ghosh describes being caught up in the first tornado ever to hit Delhi. As a novelist accustomed to mining his own life story for material, he felt the experience should have been a gift for his writing - but every time he tried to translate it into a novel, he failed. The incident was too improbable: as a reader, he would never believe it. He came to agree with the literary theorist Franco Moretti, who argues that novels actively conceal the 
exceptional moments that drive narrative in a way that earlier stories - Ghosh cites The Arabian Nights and The Decameron - never did. Moretti coined the term "filler" for a type of insertion that is typical of the nineteenth-century novel. He means a preponderance of everyday details that act like good manners in Jane Austen: they "keep the "narrativity' of life under control" (cited in Ghosh 2016: 17). Improbable events are relegated to the background and the everyday moves into the foreground. This "rhetoric of the everyday" calms and rationalises life in a way that Moretti describes as offering "the kind of narrative pleasure compatible with the new regularity of bourgeois life" (19).

Assumptions that life is orderly and predictable make no sense in the Anthropocene. Yet Ghosh does not see literary fiction adapting to the times. He acknowledges that improbable events abound in surrealist and magical realist novels, but argues that the problem with treating extreme weather events as surreal or magical is that this means robbing them of "precisely the quality that makes them so urgently compelling - which is that they are actually happening on this earth, at this time" (27).

By contrast, the acousmatic story has many features that enable it to incorporate improbable events while still remaining credible. Arguably the most powerful of these is the most obvious: it is a sonic rather than a visual form. For the reader to accept that previously improbable events, such as extreme weather situations, are now part of the "new normal", a change in perspective is needed. This is where the sense of hearing can come in. In a culture that is predominantly visual, sound tends to be taken for granted. In this context, listening has "a certain subversive quality to it", as Christos Carras puts it (2019: 265). Carras is writing about soundwalking, the practice of going for a walk with the sole purpose of listening to the environment. However, his comments could apply equally to acousmatic storytelling. By requiring the audience to focus on the sense of hearing rather than sight, it "goes against the grain of our dominant visual culture, shifting our perceptual centre of gravity, thus displacing our awareness and heightening our sensitivity to the environment we are in" (265).

Alongside this perspective-altering focus on sound, the acousmatic story is supple enough to be able to present a number of interwoven versions of the same story. Amelides illustrates this with reference to his own work Alexandros (2012), which was inspired by the Greek politician Alexandros Panagoulis (1939-76), who was active in the fight against the junta in Greece from 1967-74 (Amelides 2016: 215). Amelides uses a number of narrators to tell Panagoulis' story: the politician's brother offers a sentimental and internal narrative; a close friend provides a more detached view of the political situation, while archive recordings of Panagoulis himself furnish accounts of his political views, fight against the junta and arrest. This provides the listener with frequent changes in perspective and an awareness that stories may be contested, disruptive and interlinked. 
The epitome of acousmatic storytelling, for Amelides, is Ricordiamo Forli (Young 2005), which relates how Young's parents met during the Second World War. The story is fraught with trauma since it is bound up with the bombing of an apartment block that killed two members of his mother's family. While it is beyond the scope of this article to give a detailed explanation of literary trauma theory, it is worth noting that traumatic experience is axiomatically seen as beyond representation in the same way that Ghosh is suggesting applies to climate change. Young uses a wide range of material, including interviews with his father, archival materials from the Imperial War Museum and soundscapes recorded in Forli to create what Amelides calls "a holistic storytelling experience" (2016: 219). Amelides' analysis of the composition demonstrates how Young's techniques enable multiple versions of this family story to be woven into a wider exploration of the experience of war and the nature of traumatic memory. This example of a powerful communication of events that are often considered beyond representation adds weight to our argument that acousmatic storytelling has great potential in the Anthropocene.

It follows that what Ghosh calls "improbable events" can easily be introduced. One way of doing this is through the insertion of what Amelides calls "abrupt sonic gestures" (2016: 219) that disrupt the narrative and shock the listener into a change of focus. For example, in an early section of Imagined Boundaries, recordings of poetry and birdsong are suddenly interrupted with the sounds of a mass of flapping wings over machinery and high pitch drones, suggesting, shockingly, the relentless, grinding progress of industrialisation during the Anthropocene and the potential evacuation of all bird life in the wake of such destructive force.

Arguably the most important feature of the acousmatic story in this context, however, is that it enables the composer to challenge the boundaries between the everyday and the so-called improbable. This is best illustrated with reference to the early weeks of the Covid-19 lockdown when, in the absence of certain urban sounds, a new aural "everyday" appeared. In the unpublished diary she kept during this time, Schauerman wrote:

At the moment town is a very different place; so I am hearing an urban soundscape that I have not heard before. These are neglected sounds, or obscured sounds, they have pitch which changes with proximity; textures that would normally evaporate into the general background of town noise. This multi-storey car park resonates, like a musical instrument; it's a resonating body, vibrating due to the air conditioning system of a nearby building (15 April 2020).

Similarly, the Royal Society for the Protection of Birds reported a spike in people searching for information to help them identify garden birdsong (Smith 2020: n.p.). The sounds had always been there; they might have been described as "everyday", but suddenly they had moved to the foreground, emphasising as they did so the profound changes that were being wrought by the virus. Through unexpected combinations of recorded and manipulated sounds, the acousmatic composer can stimulate similar reassessments of what should be considered everyday and what improbable. Such disruptions 
of habitual patterns of thought that are brought about by alterations in process or routine have the potential to effect change. As Carras puts it: "they are experiential and impact the way in which we imagine our world, and at the same time, through this shift in perspective, open up the possibility of imagining that it could be otherwise" (2019: 265).

Thus acousmatic storytelling lends itself to revealing rather than concealing the multiple crises of the Anthropocene. It does this by challenging accepted boundaries, for example between the improbable and the everyday, as argued above. This ability to transcend such boundaries is intrinsic to its hybrid nature, the way it weaves storytelling techniques with electroacoustics and explores the synergy between them (Amelides 2016: 213). By contrast, many of the problems that Ghosh identifies within serious literary fiction arise from its tendency to resist hybrids and enforce boundaries. The most drastic of these is the division between nature and culture that has been a feature of Western epistemology since Descartes, as we will now discuss.

\section{Entangled stories}

Ghosh argues that serious literary fiction has been particularly active in enforcing the nature-culture split, especially since the end of the nineteenth century, and thus precisely when "the accumulation of carbon in the atmosphere was rewriting the destiny of the earth" (2016: 7). In this period, he argues, "nature" increasingly became seen as something confined to the sciences and thus off limits to culture. Ghosh's criticisms resonate with much recent work in philosophy and cultural theory that falls under the heading of "new materialism". New materialism draws on developments in science such as relativity theory and quantum mechanics to challenge the longstanding (Western) idea that matter is static and inert and that attributes such as creativity and agency belong solely to humans. New materialist thinkers posit instead that matter has "intrinsic vitality" (Bennett 2010: 3). In addition, humans and nonhumans are entangled in such a vast mesh of agencies that it is no longer possible to think of separate, individually determinate entities.

This has significant implications for the way we think about stories. As Serenella Iovino puts it, that which has been previously considered inert matter is rather "a site of narrativity, a storied matter, a corporeal palimpsest in which stories are inscribed" (2012: 451). In her book on the subject written with Serpil Oppermann, they elaborate as follows:

[T] he world's material phenomena are knots in a vast network of agencies, which can be 'read' and interpreted as forming narratives, stories. Developing in bodily forms and in discursive formulations, and arising in coevolutionary landscapes of natures and signs, the stories of matter are everywhere: in the air we breathe, the food we eat, in the things and beings of this world, within and beyond the human realm. All matter, in other words, is a 'storied matter' (2014: 1). 
Stories are not a human invention: stories are everywhere around us and humans cannot hope to be good storytellers unless they recognise that both they themselves and the stories they tell are inextricably entangled with the constantly emerging stories of other-than-human beings and things. ${ }^{2}$

Acousmatic storytelling is ideally suited to highlighting the different entanglements, emergences and connections that Iovino and Oppermann describe. Again we argue that this arises mainly from its sonic nature. Sound is intrinsically relational. As Gilmurray points out, "Sound's unique ability to reveal the system of dynamic relationships that exists between things in the world is ... a fundamental pillar of acoustic ecology" (2017: 38). For Carras, sound "unites those who listen in a kind of community that is physical and sensual" (2019: 265). "Those who listen" might refer to the different members of the audience for an acousmatic story, who are connected to one another through their experience of listening. More importantly in the context of the Anthropocene, though, "those who listen" are not just human beings. When we work with birdsong recorded on Dobson's allotment, for example, we are aware that all kinds of entities are engaged in listening to the same sounds: other plot holders; families in the adjoining park; and other-than-human animals such as badgers, rats, worms and woodlice to name just a few, and not forgetting the birds themselves.

Additionally, entities that may not "hear" in the usual sense of the word, such as soil, grass, sheds and spades are affected by the vibrations of the sound working on their bodies. Scientists working in the field of bio-acoustics have demonstrated that the beach evening-primrose Oenothera drummondii, for example, produces sweeter nectar within three minutes of being exposed to playback sound of a flying bee or to synthetic sound signals at similar frequencies (Veits, Kahir, Obolski et al 2019). Discoveries like this undermine human exceptionalism, one of the drivers of the Anthropocene. As Kanngieser puts it: "(E)verything vibrates on some frequency and is touched by vibration, regardless of how imperceptible to human sensibility this might be (2015: 81). In our work on the allotment, we recognise ourselves as being drawn into a community with all these entities through the shared experience of listening. Furthermore, there is a sense in which we actually become part of the sound itself when it vibrates on our bodies. The "separation, compartmentalisation and privatisation" that often characterises modern life is subverted (Carras 2019: 265) and we come to "an embodied understanding of our embeddedness within an interconnected ecosystem" (Gilmurray 2017: 40). We

2 It is important to make the point that not all the insights of the "new materialism" are new. Early in The Great Derangement, Ghosh describes how his childhood in Bengal was imbued with a sense of the "urgent proximity of nonhuman presences" (2016: 5). On a visit to the Sundarbans, he finds the land to be "demonstrably alive", a protagonist rather than "a stage for the enactment of human history" (6). This chimes with animist thought, which has always recognised that not all persons are human and that life is necessarily relational (Harvey 2006: xiv). It is Western Enlightenment epistemology that has insisted on human exceptionalism and the split between nature and culture. 
are drawn into the multiple stories of the place even as we work on our own process of storytelling.

Ghosh uses the term "discontinuities" to refer to these ideas of separation and compartmentalisation. He is particularly critical of the way that "literary fiction" creates "discontinuities of place" (2016: 59). In "literary fiction", setting is an important element in the unfolding of the story, but setting is a bounded idea, relegating place to something like a stage set and detaching it from the vast networks of which it is part. It is easy to see how a form that relies on a bounded, disconnected idea of place would be inadequate for portraying climate change, which is so vast and all-pervasive that environmental philosophers such as Timothy Morton (2013) argue that it exceeds the very idea of location. By contrast the acousmatic story, as we have indicated above, can reveal unexpected and important connections in the vast networks of place.

Ghosh levels a similar criticism at the novel in terms of the way it deals with time. Whereas epic can range across epochs and continents, literary novels "conjure up worlds that become real precisely because of their finitude and distinctiveness". Ghosh continues:

Within the mansion of serious fiction, no one will speak of how the continents were created, nor will they refer to the passage of thousands of years: connections and events on this scale appear not just unlikely but also absurd within the delimited horizon of a novel (61).

However, the Anthropocene operates on inconceivably vast scales, both temporally and spatially, and with such insistence that it is no longer possible to exclude them from the stories we tell about our times. ${ }^{3}$ Our explorations in acousmatic storytelling suggest that it is well able to negotiate scale, from the intimate to the epochal. Amelides argues that it "enables a kind of 'sonic time travel', bringing past events back into the present and allowing the construction of hybrid combinations of past and present" (2016: 214). This is true of Imagined Boundaries, in which time is fluid, moving between different periods in a non-linear way. Recordings from the 1960s of scientists denying the link between environmental degradation and pesticides mingle with the remembered past as Dobson and her mother discuss birdwatching trips in the 1970s during a telephone conversation. Different sonic elements are used to evoke an imagined past, from a recording of John Milton's account of the creation of the birds to manipulated sounds from a building site that convey the march of industrialisation. An unsuccessful attempt to record nightjars on the outskirts of Sheffield resulted in an eerie soundtrack of absence that evokes a future without birdsong.

Additionally, our work is extending Amelides' idea that the acousmatic story is "co-created" with the listener. Amelides believes that acousmatic storytelling "transmits a unique version of a story to the mind of the listener, who

3 It is worth noting that problems of scale framing are dealt with more fully by Timothy Clark $(2012$; 2015), who also uses the term "derangement" to describe "the way people often talk about the environment" (2015: 37). 
participates in the creation of the story and acts as co-creator" (2016: 213). We agree with this but would also cite the birds, weather, grasses and so on, as co-workers in the composition and thus as instrumental in its creation. We would additionally acknowledge the SARS-CoV-2 virus as co-creator, since the lockdown forced us into new ways of creating, both separately and together. Meaning and matter have emerged together: there is no separating them.

\section{Language issues}

This leads us to the final part of the Stories chapter in The Great Derangement, in which Ghosh considers language and suggests that the Anthropocene may be "resistant to language itself". Continuing his critique of serious literary fiction, he accuses it of being complicit in the "deepening logocentrism of the past several centuries" (2016: 83). Since the invention of the printing press, he writes, the visual elements of texts have progressively declined and humans are now trapped in a "dwindling world [of] their own abstractions and concepts" (84). He believes that hybrid texts in which image and word are intertwined offer a way out of this impasse, but our work with Imagined Boundaries suggests that the acousmatic story is at least as important. This is not just because of the shift in perception brought about by privileging the sense of hearing, but also because of the opportunities for incorporating other-than-human signifying systems. The use of birdsong, for example, highlights the fact that meaning-making is not exclusively the province of humans. Additionally, human thought is not exclusively linguistic. It is interesting that when Ghosh makes this point, the examples he cites to back it up are all sonic ones:

(W)e are constantly engaged in patterns of communication that are not linguistic: as, for example, when we try to interpret the nuances of a dog's bark; or when we listen to patterns of birdcalls; or when we try to figure out what exactly is portended by a sudden change in the sound of the wind as it blows through trees. None of this is any less demanding, or any less informative, than, say, listening to the news on the radio (2016: 82).

The acousmatic story offers the listener a chance to tune in to these other forms of communication and to extend their ability to interpret, for example, shifts in the sounds made by more other-than-human entities.

Before we conclude this section, it is necessary to make a point about fiction and nonfiction. In The Great Derangement, Ghosh is explicitly critiquing a fictional form, the novel. Part of his evidence for its failure is that even successful novelists such as Arundhati Roy and Paul Kingsnorth, both of whom think deeply about the environmental crisis, have turned to nonfiction in order to write about it (2016: 8). In Amelides' framing, the acousmatic story is also nonfiction: he suggests that the composers of acousmatic stories are like historians or journalists (Amelides 2016: 213). However, we would argue that any strict division between fiction and nonfiction is another "imagined 
boundary". The acousmatic story has something in common with the increasingly popular literary genre of creative nonfiction, in which nonfiction stories are told using techniques of fiction such as character, dialogue and lyrical description. Imagined Boundaries offers an example of how this can work in the acousmatic story by way of Schauerman's experiments with the challenge of representing the Anthropocene. She has created a kind of Anthropocene leitmotif consisting of an amalgam of industrial sounds and high frequency metallic drones that uses field recordings made at a building site. She selected the segments she wanted to use, keeping some of them raw and then manipulating others. Using audio software, she stretched some of the sounds, lowered their pitch, separated and highlighted the tonal material and used reverb to create a sense of scale. The quality she wanted to capture was one of relentless moving forward, construction and an idea of scarring.

The point here is to recognise that all storytelling is a creative act in which the storyteller makes choices about what to include, and how, and what to leave out. We are not suggesting that the acousmatic story can replace the novel as a purely fictional form, but rather underlining another way in which, through its challenge to accepted boundaries, it may be considered fitting as a mode of storytelling in the Anthropocene.

\section{Limitations}

We have been enthusiastic about the potential of the acousmatic story. We recognise, however, that we are just at the beginning of our explorations in this underused form and have yet to encounter all its possible shortcomings. For example, the editors of this special issue of Cadernos pointed out that the "abrupt sonic gestures" we use to convey the threat that industrialisation has posed to the more-than-human world, risk functioning like the machine in Leo Marx's The Machine in the Garden (1964). Marx identifies a trope in American literature in which the pastoral idyll is persistently interrupted by technology, representing the industrialisation of the nineteenth and twentieth centuries. The machine is "a sudden, shocking intruder on a fantasy of idyllic satisfaction" (2000: 23). The effect of this is to sediment the nature-culture split that we have identified as so problematic. We hope, however, that we will be able to resist this by not setting up the idyllic fantasy in the first place. It is significant that our principal recording site is an allotment situated beside a busy road. It is rarely free from the sound of traffic and it is not a rural retreat like Thoreau's cabin, but rather a place of hard work where we grow essential food for the table.

It is more difficult to resolve an inherent tension in the acousmatic story's fundamental dependency on the very technologies that are part of the consumer culture we critique. There is no perfect solution to this: we too are enmeshed in the mess. That said, Schauerman's approach to composition does not rely on sophisticated, resource-intensive equipment but simply a ZOOM 
H2 Handy recorder for field recordings, a basic laptop containing open source "Audacity" multi-track editor software for manipulating and mixing sound, and the open source PaulStretch plug-in.

\section{Conclusion}

Humans have always used storytelling to make sense of the world, and as the Anthropocene continues to bring unpredictable and dramatic change, stories will be needed more than ever. Our growing awareness of the mesh-like nature of the cosmos, in which everything is connected to something else, demands capacious, flexible and hybrid forms of storytelling that can expose rather than conceal the crises of the age. Acousmatic storytelling, with its weaving of recorded and transformed sound, and its ability to draw on a huge range of sonic sources from many different spheres of activity, is one such form. Acknowledging the potential of all kinds of human and other-than-human entities to act as co-creators of the work, and drawing the listener into her own unique version of the story, it has the potential to expand our understanding of the times in which we live, as well as to stimulate us to imagine how things might be different. This hitherto relatively unexplored form of storytelling deserves closer attention and it is to be hoped that an increasing number of practitioners will be drawn to experiment with it.

\section{References}

Abbas, Sadia. 2018. "Of Things to Come: Review of Amitav Ghosh's The Great Derangement." The bto Review, April 4. Available at www.boundary2.org/2018/04/sadia-abbas-ofthings-to-come-review-of-amitav-ghoshs-the-great-derangement/

Amelides, Panos. 2016. "Acousmatic Storytelling”. Organised Sound 21(3): 213-221.

Bennett, Jane. 2010. Vibrant Matter: A Political Ecology of Things. Durham, NC: Duke University Press.

Carras, Christos. 2019. "Soundwalks: An Experiential Path to New Sonic Art". Organised Sound 24(3): 261-273.

Clark, Timothy. 2012. "Scale". Pp 148-166 in Telemorphosis: Theory in the Era of Climate Change, vol. 1, edited by T. Cohen. Ann Arbor: Open Humanities Press.

Clark, Timothy. 2015. Ecocriticism on the Edge. London: Bloomsbury.

Comstock, Michelle and Mary E. Hocks. 2016. "The Sounds of Climate Change: Sonic Rhetoric in the Anthropocene, the Age of Human Impact”. Rhetoric Review 35(2): 165-175.

Ghosh, Amitav. 2016. The Great Derangement: Climate Change and the Unthinkable. Chicago: Chicago University Press.

Gilmurray, Jonathan. 2017. "Ecological Sound Art: Steps Towards a New Field. Organised Sound 22 (1): 32-41.

Grove, Jairus. 2019. Savage Ecology: War and Geopolitics at the End of the World. Durham, NC: Duke University Press. 
Haraway, Donna. 2016. “Tentacular Thinking: Anthropocene, Capitalocene, Chthulucene”. Pp 30-57 in D. Haraway, Staying With the Trouble: Making Kin in the Chthulucene. Durham, NC: Duke University Press.

Harvey, Graham. 2006. Animism: Respecting the Living World. New York: Columbia University Press.

Heise, Ursula K. 2018. "Climate Stories: Review of Amitav Ghosh's The Great Derangement." The bto Review, 19 February. Available at https://www.boundary2.org/2018/02/ursula-k-heise-climate-stories-review-of-amitav-ghoshs-the-great-derangement/

Ingram, David. 2010. The Jukebox in the Garden: Ecocriticism and Popular Music Since 1960. Amsterdam: Rodopi.

Iovino, Serenella. 2012. "Stories From the Thick of Things: Introducing Material Ecocriticism". Part 1 of S. Iovino and S. Oppermann, "Theorising Material Ecocriticism: A Diptych." ISLE 19(3): 448-60.

Iovino, Serenella and Serpil Oppermann. 2014. "Introduction: Stories Come to Matter." Pp. 1-17 in Material Ecocriticism, edited by S. Iovino and S. Oppermann. Bloomington: Indiana University Press.

Krause, Bernie. 2012. "The sound of a damaged habitat". The New York Times, 28 July. Available at < https://www.nytimes.com/2012/07/29/opinion/sunday/listen-to-thesoundscape.html>

Macfarlane, Robert. 2016. "Generation Anthropocene: How Humans Have Altered the Planet for Ever". The Guardian, 1 April. Available at <https://www.theguardian.com/ books/2016/apr/01/generation-anthropocene-altered-planet-for-ever>

Marx, Leo. 2000 [1964]. The Machine in the Garden: Technology and the Pastoral Ideal in America. New York: Oxford University Press USA.

Moore, Jason W. 2017. "The Capitalocene, Part 1: On the Nature and Origins of our Ecological Crisis". The Journal of Peasant Studies, 44(3): 594-630

Morawitz, Falk. 2019a. "Multilayered narration in electroacoustic music composition using nuclear magnetic resonance data sonification and acousmatic storytelling." Proceedings of the International Conference on Auditory Display, Northumbria University, 23-27 June.

Morawitz, Falk. 2019b. "Portfolio of Original Compositions". Unpublished PhD thesis. Available at <https://www.research.manchester.ac.uk/portal/en/theses/portfolio-of-original-compositions(ce8b7834-cfae-4f8e-8689-05984390a33c).html>

Morton, Timothy. 2013. Hyperobjects: Philosophy and Ecology After the End of the World. Minneapolis: University of Minnesota Press.

Mukherjee, Neel. 2016. "How Global Warming has Frozen Fiction." New Statesman 30 September-6 October: 57-59.

Paiva, Daniel and Eduardo Brito-Henriques. 2019. "A Podcast on Urban Ruins, or the Aural Weaving of Theory and Field". Cultural Geographies, 26(4): 535-540.

Pasoulas, Aki. 2020. "The Art and Science of Acoustic Ecology". ent and audiology news, 28(6). Available at< https://www.entandaudiologynews.com/features/audiology-features/post/the-art-and-science-of-acoustic-ecology>

Smith, Becca. 2020. "Connecting with Nature Despite Difficult Times: A Suite of Resources". Available at <https://www.rspb.org.uk/about-the-rspb/about-us/media-centre/ press-releases/connecting-with-nature-despite-difficult-times-a-suite-of-resources / >

Subramanian, Meera. 2019. "Anthropocene now: influential panel votes to recognise Earth's new epoch". Nature, 21 May. Available at https://www.nature.com/articles/d41586019-01641-5. 
Taylor, Jesse Oak. 2018. "The Novel After Nature, Nature After The Novel: Richard Jefferies's Anthropocene Romance." Studies in the Novel 50(1): 108-133.

Veits, Marine, Itzhak Khair, Uri Obolski et al. 2019. "Flowers Respond to Pollinator Sound Within Minutes by Increasing Nectar Sugar Concentration." Ecology Letters 22: 14831492.

Westerkamp, Hildegard. 2002. "Linking Soundscape Composition and Acoustic Ecology." Organised Sound 7(1): 51-56

Young, John. (2009) "Narrative, rhetoric and personal: Storytelling in acousmatic music." Proceedings of the Electroacoustic Music Studies Conference, Buenos Aires, Argentina. Retrieved 4 March 2021 < http://www.ceiarteuntref.edu.ar/young>

Young, John. 2018. "Figures of Speech: Oral History as an Agent of Form in Electroacoustic Music". Leonardo Music Journal 28(1): 88-94

Yusoff, Kathryn (2019). A Billion Black Anthropocenes or None. Minneapolis: University of Minnesota Press.

\section{Discography}

Amelides, Panos. 2012. Alexandros_Binaural_4824. Available at <https://soundcloud.com/ panosamelides/alexandros_binaural_4824>

Young, John. 2007. Ricordiamo Forlì. On Lieu-Temps. Montreal, Empreintes Digitales, IMED0787-DVD-audio.

Date received: 2020-07-29

Date accepted: 2021-03-27 